\title{
Perceived credit constraints in the European Union
}

\author{
Erik Canton Isabel Grilo Josefa Monteagudo \\ Peter van der Zwan
}

29-10-2012

\begin{abstract}
The promotion and support of small and medium-sized enterprises (SMEs) forms an essential ingredient of the policies designed to help improve Europes economic performance. A key issue is whether SMEs face difficulty obtaining bank loans. Using pre-crisis survey data from 2005 and 2006 for nearly 3,500 SMEs (firms with fewer than 250 employees) in the European Union (EU), we investigate the determinants of perceived bank loan accessibility at the firm level and at the country level. Based on hierarchical (multi-level) binomial logit regressions, our findings show that the youngest and smallest SMEs have the worst perceptions regarding access to bank loans. The SMEs in nations with concentrated banking sectors are more positive about loan accessibility. In addition, a high fraction of foreign-owned banks is associated with improved perceptions regarding loan accessibility in the EU 15 but not in the EU 10.
\end{abstract}

Keywords: Bank loans; Money supply; SMEs; Credit constraints; Concentration index; Multi-level

JEL codes: E44; E51; G15; G21 


\begin{tabular}{|c|c|}
\hline \multicolumn{2}{|c|}{ ERIM Report Series Research in Management } \\
\hline ERIM Report Series reference number & ERS-2010-001 \\
\hline Date of publication & $2012-10-29$ \\
\hline Version & October 2012 \\
\hline Number of pages & 22 \\
\hline Persistent URL for paper & http://hdl.handle.net/1765/17699 \\
\hline Email address corresponding author & vanderzwan@ese.eur.nl \\
\hline Address & $\begin{array}{l}\text { Erasmus Research Institute of Management } \\
\text { (ERIM) } \\
\text { RSM Erasmus University / Erasmus School } \\
\text { of Economics } \\
\text { Erasmus University Rotterdam } \\
\text { PO Box } 1738 \\
3000 \text { DR Rotterdam, The Netherlands } \\
\text { Phone: +31104081182 } \\
\text { Fax: +31104089640 } \\
\text { Email: info@erim.eur.nl } \\
\text { Internet: http://www.erim.eur.nl }\end{array}$ \\
\hline Availability & 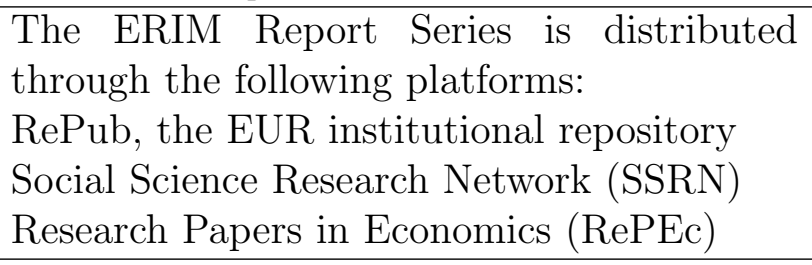 \\
\hline Classifications & $\begin{array}{l}\text { The electronic versions of the papers in the } \\
\text { ERIM Report Series contain bibliographic } \\
\text { metadata from the following classification } \\
\text { systems: } \\
\text { Library of Congress Classification (LCC) } \\
\text { Journal of Economic Literature (JEL) } \\
\text { ACM Computing Classification System } \\
\text { Inspec Classification Scheme (ICS) }\end{array}$ \\
\hline
\end{tabular}




\title{
Perceived credit constraints in the European Union
}

\author{
Erik Canton $^{\mathrm{a}}$, Isabel Grilo ${ }^{\mathrm{b}}$, Josefa Monteagudo ${ }^{\mathrm{b}}$ and \\ Peter van der Zwan ${ }^{\mathrm{c}, \mathrm{d}}$
}

\author{
${ }^{a}$ Ecorys Nederland, Rotterdam, the Netherlands \\ erik.canton@ecorys.com \\ ${ }^{\mathrm{b}}$ DG Economic and Financial Affairs, \\ European Commission, B-1049, Brussels, Belgium \\ isabel.grilo@ec.europa.eu \\ josefa.monteagudo@ec.europa.eu \\ ${ }^{\mathrm{C}}$ Erasmus School of Economics, \\ Erasmus University Rotterdam, P.O. Box 1738, 3000 DR Rotterdam, the Netherlands \\ vanderzwan@ese.eur.nl \\ ${ }^{\mathrm{d}}$ Panteia/EIM Business and Policy Research, Zoetermeer, the Netherlands
}

\begin{abstract}
The promotion and support of small and medium-sized enterprises (SMEs) forms an essential ingredient of the policies designed to help improve Europe's economic performance. A key issue is whether SMEs face difficulty obtaining bank loans. Using pre-crisis survey data from 2005 and 2006 for nearly 3,500 SMEs (firms with fewer than 250 employees) in the European Union (EU), we investigate the determinants of perceived bank loan accessibility at the firm level and at the country level. Based on hierarchical (multi-level) binomial logit regressions, our findings show that the youngest and smallest SMEs have the worst perceptions regarding access to bank loans. The SMEs in nations with concentrated banking sectors are more positive about loan accessibility. In addition, a high fraction of foreign-owned banks is associated with improved perceptions regarding loan accessibility in the EU 15 but not in the EU 10.
\end{abstract}

Keywords: Bank loans, Money supply, SMEs, Credit constraints, Concentration index, Multi-level

JEL Classifications: E44, E51, G15, G21

Corresponding author: Peter van der Zwan, vanderzwan@ese.eur.nl, tel.:+31 104081727.

Acknowledgements: The authors are listed in alphabetical order. At the time of writing this paper, Erik Canton was employed at the European Commission (DG Enterprise and Industry). The views expressed here are those of the authors and should not be attributed to Ecorys or the European Commission. The authors would like to thank Jozef Konings, Jacques Mairesse, Roy Thurik, seminar participants at the European Commission and Erasmus University Rotterdam, and two anonymous reviewers for useful comments. This study benefitted from a grant by the "Van Cappellen Stichting".

An updated version of the present paper has been accepted by Small Business Economics 


\section{Introduction}

For many years, the European Union (EU) has identified the promotion of small and medium-sized enterprises (SMEs) as being of vital importance, not least because of the oftendiscussed relationship between entrepreneurship and economic prosperity (Carree and Thurik 2007, 2010; Van Praag and Versloot 2007). SME promotion is a significant component of the strategy for improving European competitiveness that was initiated in Lisbon at the European Council meeting in March 2000. This initiative was further strengthened in 2005 with the relaunch of the Lisbon Strategy and was brought to the fore by the Small Business Act in 2008, which is consistent with the aims of the new Europe 2020 Strategy. In this context, the question of whether SMEs face (undue) difficulty in trying to obtain forms of external financing such as bank loans is pressing. Restricted access to bank loans can arise because of information asymmetry between the lender and the borrower if the banks cannot determine the quality of the projects undertaken by the borrowing SME. It is believed that SMEs may be especially sensitive to informational asymmetry because of the greater perceived opacity of small and young firms.

The aim of the current paper is to shed more light on the factors that affect perceptions regarding access to bank loans by European SMEs with fewer than 250 employees, both at the firm level and at the country level. For this purpose, we employ a 2005/2006 Eurobarometer dataset from the European Commission that includes detailed financing information for almost 3,500 SMEs in the European Union (EU 25). At the firm level, we are interested in whether perceived loan accessibility is dependent on firm age and firm size. The between-country variation in perceptions is linked to several characteristics of the banking sector. These characteristics include the degree of concentration of the banking system, the percentage of foreign-owned banks, and the average bank size. Hierarchical multi-level regressions are performed to assess the impacts of firm age, firm size, and the three banking sector characteristics on perceived loan accessibility.

There has been significant research performed to determine whether cash flow has a positive impact on firm growth, indicating credit constraints (Wagenvoort 2003a). We also note that there has been much research (more theoretical than empirical) on under-investment given the socially optimal levels (De Meza and Webb 1987; De Meza 2002). Denial rates for loan applications and their determinants have also received considerable attention (Levenson and Willard 2000). The present paper adds to the current knowledge of restricted access to finance by SMEs in at least two ways. First, this paper focuses on bank loans. This focus is important because banks are by far the most used financial institution when SMEs need financing (Petersen and Rajan 1994). Although some cross-country studies exist on the more general concept of financing obstacles to firm growth (Clarke et al. 2006; Beck et al. 2006; 2008), there have been no direct assessments of SMEs' access to bank loans in both developed and less developed nations. Furthermore, this paper's focus on bank loans is deeper because the countryspecific variables are all related to the structure of the banking sector.

Second, there has not been much work on what affects the actual perceptions of SMEs regarding their access to bank loans, although such information will be vital if we want to encourage the creation and growth of SMEs. Concentrating on SME perceptions enables a large-scale analysis because information on such perceptions is available for every firm in our 
sample. Hence, our sample also includes firms that require loans but do not apply for them because they fear that they will be rejected. Such discouraged firms form a substantial part of all SMEs (Han et al. 2009) and should not be neglected in studies of credit accessibility (Chakravarty and Xiang 2009). Note that we use a representative sample of all SMEs in the EU. SMEs represent 99\% of all enterprises in the EU, and SMEs are responsible for $85 \%$ of total employment growth (De Kok et al. 2011).

Our multi-level regression results at the firm level reveal that the youngest and smallest SMEs perceive it to be more difficult to access bank loans than do older and larger SMEs. At the country level, we find that SMEs in nations with concentrated banking sectors are more positive about loan accessibility on average than are SMEs in nations with less concentrated banking sectors. Furthermore, the existence of a high fraction of foreign-owned banks in a particular country is associated with more positive perceptions of loan accessibility, but only in the EU 15. It must be stressed that the survey data were collected well before the economic crisis. Thus, the results presented here describe the more structural elements of the relationship between perceived access to credit and the firm-level and country-level determinants studied in a "normal" economic situation.

This paper is structured as follows. Section 2 presents an overview of the related literature and presents the main conjectures to be tested. In Section 3, the data are discussed. (The data are derived from a questionnaire that asked almost 3,500 SMEs in the European Union about their perceptions regarding access to bank loans and other firm-specific characteristics.) The results are presented in Section 4, and Section 5 reveals the outcomes of our additional analyses. Section 6 concludes the paper.

\section{The factors that determine perceived loan accessibility}

Numerous studies have attempted to find direct evidence of financing constraints related to bank loans. For example, studies have investigated the funding granted relative to the funding requested (Freel 2007, Parker and Van Praag 2006) or have focused on the actual denial of bank loan requests (Levenson and Willard 2000; Storey 2004; Kim 2006). The present paper focuses on SMEs' perceptions of the accessibility of bank loans instead of analyzing objective information regarding the success of loan applications. By investigating perceptions of loan accessibility, we also consider so-called discouraged borrowers. Discouraged borrowers require loans but do not apply for them because they fear that they will be rejected. Such borrowers are rarely investigated, but they comprise a non-negligible pool of firms (Levenson and Willard 2000) and should not be omitted from studies of credit accessibility (Chakravarty and Xiang 2009). The present section will draw on studies on the concept of borrower discouragement to introduce the firm-level and country-level factors that determine SMEs' perceptions of loan accessibility.

\subsection{Firm-level determinants: firm size and firm age}

In their theoretical contribution, Kon and Storey (2003) postulate that the extent of borrower discouragement depends on bank screening errors, application costs for firms, and the difference between the bank's interest rate and that of other lenders. Importantly, the degree to which banks are informed about borrowers' projects and prospects - or the (in)ability of banks to distinguish between the relative quality of potential borrowers - is an important factor in the 
prevalence of discouraged borrowers. More specifically, Kon and Storey (2003, p. 47) conclude, "Discouragement is therefore at maximum where there is some, but not perfect, information." In addition, Han et al. (2009, p. 416) state that "Imperfect information lies at the heart of the concept of discouraged borrowers (...)." More generally, asymmetric information has played a prominent role in the theoretical and empirical work on financing constraints, which does not necessarily consider bank loans (Stiglitz and Weiss 1981; De Meza and Webb 1987).

This information asymmetry may arise if the firm, as an "insider" (Williamson 1975), is better informed than the "outsiders" (the market). It is commonly believed that this effect is accentuated with smaller firms, partially because larger firms have better accounting records and are obliged to obey the strict regulations that they must follow to be publicly listed. For example, firms with certified audited financial statements are generally larger and more transparent. Also, smaller firms can be more reluctant to be fully open about their ownership structures and strategic goals. Thus, greater transparency exists among the larger firms relative to the smaller ones. Furthermore, monitoring costs, which tend to be fixed, more drastically impact smaller-scale projects (Beck et al. 2006).

A firm's reputation or track record can also play an important role in reducing the degree of information asymmetry. Younger firms have a limited credit history (Gertler 1988; Devereux and Schiantarelli 1990; Wagenvoort 2003a, 2003b; Beck et al. 2006; Cabral and Mata 2003). ${ }^{1}$ Their restricted credit history makes it difficult for banks to predict the future probability of loan repayment.

Although firm size and firm age have traditionally been seen as important determinants of asymmetric information (Gertler 1988), this relationship has rarely been tested (Hyytinen and Pajarinen 2008), and the opposite hypothesis may also be valid. For example, smaller firms have simpler informational systems than larger firms, which could reduce the opaqueness of small firms. In addition, the Enron and Parmalat scandals have clearly shown that larger companies can also be opaque with regard to information. Hyytinen and Pajarinen (2008) further explore the conventional wisdom that small and young firms are informationally opaque by comparing data from two credit information companies and examining their disagreements about the creditworthiness of firms. The researchers find that the disagreements regarding ratings are inversely related to firm age, but they do not obtain a robust relationship between such disagreements and firm size. These authors conclude that firm age is the main proxy for information asymmetry rather than firm size (measured as total assets, total number of employees, or total net sales in their study).

Based on these insights, we empirically investigate the importance of firm age and firm size as determinants of perceived loan accessibility. We suggest that younger and smaller SMEs are likely to be more negative about loan access than are older and larger SMEs.

\subsection{Country-level determinants: banking sector structure}

Many existing studies of access to credit have a single-country focus. We use an international dataset that includes information on 25 EU Member States. This breadth allows us to explore whether cross-country variations in perceived access to loans can be explained by

\footnotetext{
${ }^{1}$ Alternatively, several authors use firm size as an indicator of the borrower's reputation. There is, however, little evidence that small firms are riskier than large companies (St. Pierre and Bahri 2011). In fact, Behr and Güttler (2007) find that the impact of firm size on default risk weakens when other control variables are included in the analysis.
} 
particular banking sector characteristics when general economic conditions are controlled for. This approach can thus reveal which aspects of the banking system most improve perceived access to bank loans. Specifically, we investigate the importance of the following features of the banking sector.

First, a concentrated banking system enables lenders to employ stricter credit conditions. Because banks exert more power in a concentrated banking sector, SMEs may be more negative about potential loan access in this type of climate. Indeed, Kon and Storey (2003) argue that borrower discouragement can be greater when there are fewer alternative sources of funding. There is empirical evidence of greater financing obstacles in such countries (Clarke et al. 2006). ${ }^{2}$ The present study tests whether concentrated banking systems in the EU are associated with negative perceptions of loan accessibility. On the basis of US data, however, Han et al. (2009) show that a more concentrated banking market is associated with less borrower discouragement. This result is somewhat surprising, though other studies have indeed shown that a more concentrated banking system - as indicated by economies of scale and scope could be more efficient (European Central Bank 2005).

In tandem with the transition process from central planning to market economies that many Eastern European countries have undergone, the foreign ownership of banks has started to increase. Thus, we investigate whether the ownership structure of banks can explain perceived loan accessibility. That is, do the SMEs in countries with more foreign-owned banks believe that access to loans is more limited than do SMEs in countries with more domestically owned banks? There is reason to believe that this could be the case: according to Berger et al. (2001, p. 2134), “(...) a foreign-owned bank may be headquartered in a very different market environment, with a different language, culture, supervisory/regulatory structure, and so forth." However, some studies also note the efficiency gains in the banking systems with more foreignowned banks, at least in some countries (Claessens et al. 2001), which could improve firms' perceptions regarding loan accessibility (The World Bank 2008, Chapter 2).

Another useful analysis of the organization of firms, information production, and the allocation of capital is Stein (2002). Stein's analysis is motivated by the concern that consolidation in the banking industry will lead to less lending to small businesses. Lending to small businesses often heavily relies on "soft" information: for instance, on the personality and competences of the owner of the SME. Small banks are argued to be more able to handle soft information. Cross-country evidence regarding access to financing relative to bank size is scarce. Our supposition is that the SMEs in countries with smaller banks are generally more positive regarding access to bank loans than are SMEs in countries with larger banks.

Finally, we control for economic development using GDP per capita. GDP per capita can partially reflect institutional quality (Clarke et al. 2006). Empirical evidence suggests that financing obstacles (although they have been differently measured in different studies) are lower in the countries with higher levels of GDP per capita (Beck et al. 2006; Clarke et al. 2006).

\footnotetext{
${ }^{2}$ However, in Clarke et al. (2006), the managers of SMEs and larger firms in developing and transition countries are not directly asked about their perceptions of loan accessibility but are rather asked about how problematic access to long-term loans is for their firm's operations and growth.
} 


\section{Data and methodology}

\subsection{Dataset}

Data are used from two identical Flash Eurobarometer Surveys on Access to Finance, of which one (No. 174) was conducted in the 15 old Member States of the European Union (EU) and one (No. 184) was conducted in the 10 newer Member States. ${ }^{3}$ The surveys were conducted on behalf of the DG Enterprise and Industry of the European Commission. Together, the datasets cover 4,583 firms in the $25 \mathrm{EU}$ countries, of which 3,047 firms (66\%) belong to the EU 15 and the remaining 1,536 firms (34\%) belong to the EU 10. Randomized telephone interviews were conducted by The Gallup Organization in September 2005 in the EU 15 and in April and May 2006 in the EU 10. Each company that was not in the agriculture, public administration, or non-profit sectors and that employed from 1 to 249 persons was eligible to participate. The person interviewed at each firm was a top-level executive, i.e., s/he worked in general management, as a financial director/manager, or as a chief accountant. The target sample sizes range from 100 to 300 SMEs for each country.

The combined dataset allows for an appropriately in-depth study of the SMEs' perceptions of the credit market and the country-level differences. The dataset enables us to look closely at which firm or banking sector characteristics could cause variability in perceptions regarding loan accessibility. Because the dataset only includes SMEs, we cannot make any inferences regarding the perceptions of credit constraints among large companies with at least 250 employees.

\subsection{Measurement}

\subsubsection{Dependent variable}

To determine the perceptions regarding loan accessibility among SMEs, we use the following question from both Flash Eurobarometer surveys: "Would you say that today, access to loans granted by banks is very easy, fairly easy, fairly difficult, or very difficult?"

We construct a dependent variable that takes a value of 1 if the answer is "very difficult" or "fairly difficult" and takes a value of 0 if the answer is "very easy" or "fairly easy."

Table 1, panel A, shows the distribution of the responses across countries. The calculations are based on the same set of firms that will be included in the hierarchical regression models in the remainder of this paper. The listwise deletion of the missing values for the firm-level variables yields a sample of 3,289 firms. All of the descriptive statistics have been weighted. The weights denote the inverse of the probability that a firm is included in the sample and have been constructed based on the true distribution of the SMEs in each country according to firm size and sector of activity.

Table 1, panel A, reveals that the views about the difficulty of access to loans are mixed: $42 \%$ of all SMEs believe that obtaining bank loans is difficult, whereas $58 \%$ perceive it to be easy. The average perceptions in the EU 15 and the EU 10 areas are similar. However, the data show significant variation across countries: $96 \%$ of all Finnish firms believe that access to loans is easy whereas $86 \%$ of the German SMEs find it difficult. An ANOVA test of the weighted averages reveals sufficient between-country variation, which justifies the use of hierarchical

\footnotetext{
${ }^{3}$ Two Member States of the European Union are not represented in the present dataset: Bulgaria and Romania joined the European Union in 2007.
} 
regressions (F-value=22.94; corresponding p-value $<0.001$ ). Specifically, hierarchical binomial logit regressions will be used to determine the sources of this cross-country variation.

Furthermore, Table 1 provides some indication of the variation in the SME perceptions based on firm age and firm size. More specifically, panel B distinguishes between the young firms (those that have been in existence for less than 10 years) and the established firms (those that have been in existence for at least 10 years) and shows that for most countries, the younger firms are indeed more negative about loan accessibility than the established firms. However, in some EU 10 countries, the relationship is less straightforward. Panel C shows the perceptions across three firm size classes: micro firms (1-9 employees), small firms (10-49 employees), and medium-sized firms (50-249 employees). The averages reveal a clear pattern: perceptions regarding access to bank loans become more positive as firm size increases. The exact relationships between firm age and firm size on the one hand and perceived loan accessibility on the other hand will be determined in a multivariate and multi-level context in the remainder of this paper.

\subsubsection{Subjective versus objective measurement}

It should be noted that we examine the perceived difficulty of access to credit and do not have data for more objective measures of the difficulty of obtaining bank loans. A selfassessment criterion based on surveys among firms is used in other studies as well. ${ }^{4}$ One advantage of this type of approach is that it allows us to include a large group of firms that would have been otherwise omitted, including discouraged borrowers. Furthermore, the perceptions of a wide range of SMEs can be more relevant than objective criteria if our aim is to understand firm behavior. The present analysis provides insight into how the initiatives intended to improve access to finance could not only benefit the firms that have (un)successfully applied for loans in the past but could also assist firms that have not applied for loans. We expect at least a moderately positive relationship between subjective and objective indicators of access to credit (see also Egeln et al. 1997). To find support for this claim, we use the Global Competitiveness Report 2005-2006 by the World Economic Forum, which contains information on the difficulty of accessing bank loans in many countries. This measure of the difficulty of accessing bank loans is based on experts' responses to the following question: "How easy is it to obtain a bank loan in your country with only a good business plan and no collateral?" Each expert rates this statement on a 7-point Likert-scale (ranging from 1=“impossible" to 7="very easy") such that each country receives a value between 1 and 7 (to 1 decimal) that indicates the difficulty of accessing bank loans. It turns out that the Pearson correlation coefficient of the weighted country averages for our perception variable and the country scores from the Global Competitiveness Report equals 0.41 (significant at a 0.05 level; 25 observations), which indeed indicates a modest positive relationship between the two measures.

\subsection{3. $\quad$ Firm age and firm size}

We construct a series of dummy variables to reflect firm age: age $<10$ if the firm has existed for fewer than 10 years; age 10-20 for a firm age between 10 and 20 years; age 20-30 for an age between 20 and 30 years; and age $>30$ if the firm has been in existence for more than 30 years. Age $>30$ is used as the reference category in our analyses. We do not include a

\footnotetext{
${ }^{4}$ Examples include Egeln et al. (1997) and Beck et al. (2006), although the firms are less directly asked about loan accessibility than in the present study.
} 
continuous specification for age because such a continuous measure is only available for the firms in the EU 15.

Again, a set of dummies is used to measure firm size. There are three size classes available that indicate the total number of employees: micro firms have 1 to 9 employees, small firms have 10 to 49 employees, and medium-sized firms have 50 to 249 employees. The group of 50-249 employees is used as the reference category in the remaining analyses.

\subsubsection{Control variables at the firm level}

Dynamic firms, both those that feature a growing number of employees and those that exhibit improved performance, are expected to be more optimistic in their perceptions regarding loan accessibility. This is because such firms may actually not feel constrained by their lack of external financing given that they can use their increasing cash flows for their financing purposes or reinvest their profits. However, it could also be argued that growing firms require greater financial inflows (Freel 2007) and that they may therefore be more negative regarding loan availability. The growth in the number of employees is captured by the variable employment. This variable takes a value of 2 if a firm's number of employees has increased since the previous year, a value of 1 if it has remained the same, and a value of 0 if it has decreased. A firm's dynamics in terms of its cash flow and investments are also taken into account. The variables cash flow and investments take a value of 2 when the firm's situation has improved in this regard since the previous year, a value of 1 if there has been no change, and a value of 0 if cash flow or investments have worsened.

Because perceptions regarding access to bank loans clearly depend on earlier experiences, we include previous loan, which takes a value of 1 when a firm has made use of a short-term or a long-term loan in the past and 0 otherwise.

Evidence has been found that foreign-owned firms have easier access to external financing than do nationally owned firms (Schiantarelli and Sembenelli 2000; Harrison and McMillan 2003; Beck et al. 2006). Hence, the ownership of the firm is controlled for using the following variables. Family takes a value of 1 if the firm is partly or exclusively family-owned and a value of 0 otherwise. Domestic equals 1 if the firm is exclusively owned by a national company and 0 otherwise. Foreign takes a value of 1 if the firm is partly or entirely owned by an international company and a value of 0 otherwise. Other ownership structures are assembled in the variable other. In our regressions, domestic is used as the reference category.

Because loan demand can vary across sectors, we control for sector-specific characteristics by using sector dummies. We distinguish between the following eight sectors: construction or civil engineering, financial services, production and manufacturing of goods, extraction or production of raw materials, trade and distribution, transport, other services to businesses, and other services to consumers. Construction or civil engineering is used as the reference category in the regression analyses.

\subsubsection{Country-level variables}

GDP per capita figures for the year 2004 have been retrieved from Eurostat. We use a logarithmic transformation of this variable, and GDP per capita is expressed in Euros (and in terms of purchasing power parity).

To measure the degree of concentration in the banking sector, the Herfindahl-Hirschman Index for 2004 is used. Concentration is measured as the sum of the squares of the market 
shares of all credit institutions according to total assets. The corresponding 2004 data can be found in European Central Bank (2005). The numbers range from 178 for Germany to 3887 for Estonia where the theoretical maximum value is 10,000 . The higher the number, the more concentrated the market is. Values higher than 1,800 usually indicate a concentrated banking industry. This threshold for distinguishing between high- and low-concentration banking markets has been used for the US bank merger guidelines (Federal Reserve Bank 1998; Han et al. 2009).

To reflect the percentage of foreign-owned banks, we use the share of the assets of foreign credit institutions as a percentage of the total assets of domestic credit institutions. The data from 2004 can be found in Allen et al. (2006). Higher numbers indicate greater foreign ownership in the banking sector. High percentages are visible in numerous EU 10 countries, including the Czech Republic, Estonia, Lithuania, and Slovakia, as well as in Luxembourg (all over 90\%). Many EU 15 countries such as Germany and Italy have low values (below 10\%).

The average bank size for the year 2004 is defined as the total assets of all credit institutions in a country divided by the number of credit institutions in that country, as a percentage of the country's GDP (calculations based on European Central Bank 2005). Higher numbers indicate larger banks in terms of their average asset value (scaled by the country's GDP).

Note that the relatively low number of countries included in the present study imposes constraints on the maximum number of variables that can be taken into account at the country level.

\subsection{Analysis}

Hierarchical (multi-level) binomial logit regressions are performed to simultaneously assess the influence of the firm-level and country-level variables on the dependent binomial variable, i.e., perceived loan accessibility. Hierarchical modeling takes into account the hierarchical structure of the dataset (Peterson et al. 2012), i.e., the 3,289 firms are nested within the 25 countries. Random intercepts are incorporated into our model to explain the betweencountry variation in the perceived difficulty of obtaining bank loans while controlling for the relevant firm-level variables (Peterson et al. 2012). The model contains country-specific intercepts that depend on country-specific variables and a normally distributed disturbance term (Block et al., 2012).

The HLM 7.0 software program is used for the multi-level analyses (Raudenbush et al. 2011). Standard errors that are robust to heteroskedastic disturbance terms are employed (for more technical details, see Raudenbush and Bryk 2002, Chapter 9). The PQL (penalized quasilikelihood) method is used to obtain coefficient estimates at the firm level and at the country level (Raudenbush and Bryk 2002, Chapter 14). The variables have not been centered around the overall means or the country means. Finally, inferences are made based on population average models rather than on unit-specific models. Raudenbush and Bryk (2002, p. 304) conclude that "population-average inferences are based on fewer assumptions and will be quite robust to erroneous assumptions about the random effects in the model."

The coefficients of the firm-level variables can be interpreted as they are in ordinary binomial logit regressions (Block et al., 2012). A significant positive (negative) coefficient implies an increase (a decrease) in the probability of finding access to bank loans difficult as the 
value of a particular variable increases. Regarding the country-level variables, a significant positive (negative) coefficient means that higher values for the particular variable are associated with a tendency of firms to perceive obtaining loans as difficult (easy) in such countries.

\section{Results}

A correlation matrix for the firm- and country-level variables is provided in Table 2. The low between-variable correlations generate no serious concerns with regard to multicollinearity. Table 2 also reports the weighted sample averages for the entire sample, the EU 15 sample, and the EU 10 sample.

The estimated coefficients of our hierarchical binomial logit regression are displayed in Table 3. Model 1 includes the firm-level variables only while allowing for a random intercept at the country level.

\subsection{Firm age and firm size}

Model 1 in Table 3 reveals that the youngest SMEs (those that have been in existence for up to ten years; p-value $<0.01$ ) have the worst perceptions about loan accessibility. This finding implies that more time allows firms to develop a track record that relaxes such perceptions. Note that the relationship between firm age and perceived loan access is non-monotonic: the firms that are 20-30 years old have the best perceptions, even compared to those that are more than 30 years old $(\mathrm{p}<0.10)$.

Firm size also influences perceived loan access. The smallest firms (1-9 employees, $\mathrm{p}<0.05$ ) have the worst perceptions. There are no significant differences in perceptions for small (10-49 employees) versus medium-sized (50-249 employees) firms ( $\mathrm{p}>0.10)$.

\subsection{Control variables at the firm level}

Significant and consistent results are found for our measures of firm dynamics. That is, firms that are growing - in terms of their number of employees $(p<0.01)$, cash flow $(p<0.01)$, or investments $(\mathrm{p}<0.10)$ - are more positive about access to bank loans than are firms that are not growing. The other control variables are insignificant ( $>0.10$ for all variables). That is, the firms that have received loans in the past are not different in terms of their perceptions from the firms that have not received loans. In addition, the ownership structure of a firm is not significantly related to its perceptions regarding loan accessibility. Lastly, a firm's sector of economic activity does not matter in this regard.

\subsection{Country-level variables}

Model 2 in Table 3 adds the country-level variables. We find that the degree of concentration in the banking sector has a strong negative influence $(\mathrm{p}<0.05)$. Contrary to our expectations, concentration improves perceived access to bank loans. Furthermore, the percentage of foreign-owned banks is not an important factor in explaining the variation in perceptions across countries ( $>0.10$ ). Finally, the average bank size is positively associated with the perceived difficulty of obtaining bank loans $(\mathrm{p}<0.10)$. This finding implies that countries with larger banks on average are characterized by unfavorable SME perceptions of loan accessibility. Our control variable, GDP per capita, is not significantly related to the crosscountry variation in perceived loan accessibility ( $\mathrm{p}>0.10)$. 
We further explore the country dimension by investigating the differences between the EU 15 and the EU 10. Interaction terms between an EU 15 dummy variable that takes a value of 1 for an EU 15 Member State and 0 otherwise and each country-level variable are consecutively added to Model 2. It appears that the percentage of foreign-owned banks is the only countrylevel variable with differential impacts between the EU 15 and the EU 10. Model 3 in Table 3 shows the relevant results, adding the interaction term EU15 $\times \%$ Foreign owned/100 to Model 2. In Model 3, the coefficient of the variable \% Foreign owned/100 indicates the impact for the EU 10 ( $>>0.10)$. An additional test of the linear combination of this coefficient and the coefficient of the interaction term shows that the percentage of foreign-owned banks has a significant negative influence for the EU $15(\mathrm{p}<0.05)$.

\section{Additional analyses}

Our first robustness check involves using a different measure of firm size, which is annual turnover instead of the number of employees. Four dummy variables are created: turnover $<500 \mathrm{k}$ if a firm's turnover in the previous fiscal year was less than $€ 500,000$, turnover 500k$2500 \mathrm{k}$ for a turnover between $€ 500,000$ and $€ 2.5$ million, turnover $2500 \mathrm{k}-5000 \mathrm{k}$ for a turnover between $€ 2.5$ million and $€ 5$ million, and turnover $>5000 \mathrm{k}$ when the previous year's turnover exceeded $€ 5$ million. Turnover $>5000 \mathrm{k}$ is used as the reference category. The estimation results presented in Model 4 replicate our findings regarding firm size: the smallest firms - those with up to an annual turnover of $€ 2.5$ million - have the worst perceptions (p-values $<0.01$ ). These firms represent $88 \%$ of all SMEs in our sample.

Firms that have received loans in the past base their assessment of loan availability on other information than firms that have not received loans. We rerun our analysis of Model 2 using the subset of firms that have received bank loans in the past, i.e., SMEs for which the variable previous loan equals 1 . The results are displayed in Model 5. The findings are qualitatively similar for Model 2 and Model 5. Again, the youngest $(p<0.05)$ and smallest $(p<0.05)$ firms have the worst perceptions even though these firms apply for considerably smaller amounts than the older and larger firms. This finding is illustrated in Table 4. Table 4 shows the most recent loan amounts for which firms have applied. Panel A of Table 4 shows that, on average, $36 \%$ of all firms that applied for a loan in the past made a recent request of less than 25,000 Euros; 37\% requested a loan of between 25,000 and 100,000 Euros, and 26\% requested more than 100,000 Euros. However, variation in these figures with reference to firm size is substantial. Whereas $43 \%$ of the micro firms requested less than 25,000 Euros, the corresponding figure is only $15 \%$ for small firms, and it is only $6 \%$ for medium-sized firms. Additionally, the percentages increase from $19 \%$ to $48 \%$ and $75 \%$ for the requests that are larger than 100,000 Euros for micro firms, small firms, and medium-sized firms, respectively (all weighted percentages). This pattern can also be observed for the separate EU 15 (Panel B) and EU 10 (Panel C) samples.

Regarding the country-level variables, the results are also qualitatively similar for Model 2 and Model 5. The relationship between perceived loan accessibility and the degree of concentration is even stronger in Model 5 than in Model $2(\mathrm{p}<0.01)$.

At the country level, we assess the robustness of our findings to the degree of concentration. An alternative measure of concentration replaces the Herfindahl index in Model 
2 with the sum of the shares of total assets of the five largest credit institutions, known as the five-firm concentration ratio (source: European Central Bank 2005). Again, the highest value is found for Estonia (98.0\%), whereas Germany ranks lowest in terms of the degree of concentration (6.3\%). This variable also has a significant negative coefficient $(\mathrm{p}<0.10)$. The exact estimation results are available from the authors upon request.

\section{Discussion and conclusion}

The determinants of perceived bank loan accessibility among SMEs play a central role in this paper, both at the firm level and at the country level. We use a firm-level dataset that contains information for nearly 3,500 SMEs in 25 European Union Member States. At the firm level, our multi-level results indicate that the youngest and smallest SMEs perceive it to be more difficult to obtain bank loans than do the older and larger SMEs. For firms, growing older establishes a track record that reduces the information asymmetry between them and banks. Our results suggest that investing time and energy in "relationship banking" could reduce these information asymmetries between the lender and the borrower and could thus improve perceived access to bank loans (Petersen and Rajan 1994, 1995; Berger and Udell 1995; Harhoff and Körting 1998; Wagenvoort 2003b). Interestingly, our results do not imply an entirely monotonic relationship between firm age and perceived loan accessibility. Indeed, firm age relaxes perceptions regarding loan accessibility, but only until a firm age of 30 years. The oldest SMEs (those that are more than 30 years old) are more pessimistic about access to bank loans than are SMEs that have been in existence for between 20 and 30 years. Hence, relationship banking may be the most useful in the earliest phase of a firm's life cycle, but these benefits may be eliminated as firms age. One explanation could be that the oldest firms are not as dependent on banks as the younger firms are because of their stronger internal financial situation (Petersen and Rajan 1994), which diminishes the strength of the older SMEs' firmbank relationships. Furthermore, the loan amounts requested by the oldest firms are relatively high (based on the present dataset), and the probability of denial could also increase as a result.

At least one other result at the firm level may indicate the importance of relationship banking and thus of asymmetric information in relaxing firms' perceptions regarding loan accessibility. The firm-level results consistently indicate that growing SMEs are more positive regarding access to bank loans than are non-growing SMEs. This result may be explained by a lower degree of information asymmetry between growing firms and banks because banks "may be more willing to invest in developing a closer working relationship with growing businesses" (Binks and Ennew 1996, p. 20). In addition, the growing firms could be more open about their internal structures because of their greater reliance on banks in planning for future investments. These results are interesting and further develop the research that finds negative (or nonsignificant) relationships between firm growth and measures of loan accessibility (e.g., Freel 2007).

There are considerable cross-country differences in terms of perceived loan accessibility. This between-country variation can be largely explained by the degree of concentration in the banking sector. Specifically, we find that a concentrated banking sector is associated with more favorable perceptions regarding access to bank loans. Our results add to the current literature that addresses the implications of the increased market power of banks (Turk-Ariss 2010). A similar relationship between access to finance and the degree of concentration is proposed in 
Han et al. (2009) and European Central Bank (2005). The current results suggest that the banks in concentrated markets are more willing to invest in relationships with SMEs than are banks in less concentrated markets, which positively influences SMEs' perceptions regarding loan accessibility. Clearly, our conclusions contradict the argument that greater concentration generates less competition between banks, which would then enable lenders to make credit conditions more strict (for empirical evidence on this subject, see Clarke et al. 2006). Similarly, other literature has supposed that that increased competition will generate improved access to external finance because it forces the incumbent banks to work more efficiently in providing financial services (The World Bank 2008, Chapter 4).

The liberalization of the financial markets in the EU 10 has led to an increased presence of foreign banks. The percentage of foreign-owned banks does not explain the cross-country variation in perceptions of loan accessibility in the EU 10 and in the EU 25 as a whole. Clearly, the suggested positive influences of foreign banks offset some of the proposed negative consequences. Furthermore, it is possible that the influence of foreign banks is heterogeneous, i.e., that certain types of firms benefit more from foreign banks than do other types of firms (Lin 2011). However, this issue was not investigated in the present paper. Interestingly, in the EU 15, the presence of more foreign-owned banks is associated with improved perceptions regarding access to bank loans. There is indeed some evidence that financing obstacles decrease in the presence of foreign banks (Clarke et al. 2006, The World Bank 2008, Chapter 2), but these analyses typically include larger firms and are restricted to developing or transition economies.

Like many other studies, this one only addresses established firms. It might be possible, for example, that restricted access to bank loans prevents the successful start up of a business (see, for instance, Aghion et al. 2007). Thus, it is possible that this study underestimates the impacts of firm age and firm size on the perceived difficulty of accessing credit because any potential entrepreneurs who cannot obtain sufficient credit to start a business are not included in the sample. Another form of potential selection bias is associated with the possibility that older firms are generally "higher quality" firms because lower quality firms are less likely to survive. In other words, when young firms perceive their access to credit to be limited, this difficulty may arise due to banks' negative risk assessments of these firms rather than to information problems.

Further research should develop better proxies for asymmetric information in attempting to analyze perceptions regarding access to bank loans or the determinants of borrower discouragement. For example, many empirical studies show that collateral provides an incentive and a means for good lenders to identify themselves (Besanko and Thakor 1987; Chan and Kanatas 1985; Bruns and Fletcher 2008; Kon and Storey 2003). This finding suggests that an increased ability to supply collateral should lead to improved perceptions regarding loan accessibility or to less borrower discouragement. Furthermore, our analysis focuses primarily on supply side constraints because the factors that are investigated are not associated with the viability of the projects themselves. Future research could more specifically explore the demand side constraints related to information and advice that may exist when firms do not obtain optimal amounts of credit due to their lack of knowledge, their inadequate presentation of their proposals, or their poor management (Cressy 2002, 2003; De Meza and Webb 1987; De Meza 2002). 


\section{References}

Aghion, P., Fally, T., \& Scarpetta, S. (2007). Credit constraints as a barrier to the entry and post-entry growth of firms. Economic Policy, 22(52), 731-779.

Allen, F., Bartilori, L., \& Kowalewski, O. (2006). The financial system of the EU 25. In K. Liebscher, J. Christl, P. Mooslechner, \& D. Ritzberger-Grunwald (Eds.), Financial development, integration, and stability: Evidence from Central, Eastern, and South-Eastern Europe (pp. 80-104). Cheltenham: Edward Elgar.

Beck, T., Demirgüç-Kunt, A., Laeven, L., \& Maksimovic, V. (2006). The determinants of financing obstacles. Journal of International Money and Finance, 25(6), 932-952.

Beck, T., Demirgüç-Kunt, A., \& Maksimovic, V. (2008). Financing patterns around the world: Are small firms different? Journal of Financial Economics, 89(3), 467-487.

Behr, P., \& Güttler, A. (2007). Credit risk assessment and relationship lending: An empirical analysis of German small and medium-sized enterprises. Journal of Small Business Management, 45(2), 194213.

Berger, A., Klapper, L., \& Udell, G. (2001). The ability of banks to lend to informationally opaque small businesses. Journal of Banking \& Finance, 25(12), 2127-2167.

Berger, A., \& Udell, G. (1995). Relationship lending and lines of credit in small firm finance. The Journal of Business, 68(3), 351-381.

Besanko, D., \& Thakor, A.V. (1987). Collateral and rationing: Sorting equilibria in monopolistic and competitive credit markets. International Economic Review, 28(3), 671-689.

Binks, M.R., \& Ennew, C.T. (1996). Growing firms and the credit constraint. Small Business Economics, 8(1), 17-25.

Block, J., Thurik, A.R., Van der Zwan, P., \& Walter, S. (2012). Business takeover or new venture? Individual and environmental determinants from a cross-country study. Entrepreneurship Theory \& Practice, doi:10.1111/j.1540-6520.2012.00521.x

Bruns, V., \& Fletcher, M. (2008). Banks' risk assessment of Swedish SMEs. Venture Capital, 10(2), 171-194.

Cabral, L.M.B, \& Mata, J. (2003). On the evolution of the firm size distribution: Facts and theory. The American Economic Review, 93(4), 1075-1090.

Carree, M.A., \& Thurik, A.R. (2007). The lag structure of the impact of business ownership on economic performance in OECD countries. Small Business Economics, 30(1), 101-110.

Carree, M.A., \& Thurik, A.R. (2010). The impact of entrepreneurship on economic growth. In D.B. Audretsch, \& Z.J. Acs (Eds.), Handbook of Entrepreneurship Research (pp. 557-594). Heidelberg: Springer Verlag.

Chan, Y., \& Kanatas, G. (1985). Asymmetric valuations and the role of collateral in loan agreements. Journal of Money, Credit and Banking, 17(1), 84-95.

Chakravarty, S., \& Xiang, M. (2009). What discourages small businesses from asking for loans? The international evidence on borrower discouragement. Available at SSRN: http://ssrn.com/abstract=1344098. Accessed 11 September 2012.

Claessens, S., Demirgüç-Kunt, A., \& Huizinga, H. (2001). How does foreign entry affect domestic banking markets? Journal of Banking \& Finance, 25(5), 891-911.

Clarke, C.R.G., Cull, R., \& Soledad Martínez Pería, M. (2006). Foreign bank participation and access to credit across firms in developing countries. Journal of Comparative Economics, 34(4), 774-795.

Cressy, R. (2002). Funding gaps: a symposium. The Economic Journal, 112(February), F1-F16.

Cressy, R. (2003). Credit constraints on small businesses: Theory versus evidence. International Journal of Entrepreneurship Education, 1(4), 515-538.

De Kok, J.M.P., Vroonhof, P., Verhoeven, W., Timmermans, N., Kwaak, T., Snijders, J., \& Westhof, F. (2011). Do SMEs create more and better jobs? Report prepared by EIM for the European Commission's DG Enterprise and Industry, Brussels: European Commission. http://ec.europa.eu/enterprise/policies/sme/facts-figures-analysis/performance-review/files/

supporting-documents/2012/do-smes-create-more-and-better-jobs_en.pdf. Accessed 11 September 2012. 
De Meza, D. (2002). Overlending? The Economic Journal, 112(477), F17-F31.

De Meza, D., \& Webb, D.C. (1987). Too much investment: A problem of asymmetric information. The Quarterly Journal of Economics, 102(2), 281-292.

Devereux, M., \& Schiantarelli, F. (1990). Investment, financial factors and cash flow from U.K. panel data. In G. Hubbard (Ed.), Information, capital markets and investment (pp. 279-306). Chicago, IL: University of Chicago Press.

Egeln, J., Licht, G., \& Steil, F. (1997). Firm foundations and the role of financial constraints. Small Business Economics, 9(2), 137-150.

European Central Bank (2005). EU banking structures. http://www.ecb.int/pub/pdf/other/ eubankingstructure102005en.pdf. Accessed 11 September 2012.

Federal Reserve Bank (1998). Concentration, the HHI, and the Department of Justice merger guidelines. Federal Reserve Bulletin, 84(9), 704-715.

Freel, M.S. (2007). Are small innovators credit rationed? Small Business Economics, 28(1), 23-35.

Gertler, M. (1988). Financial structure and aggregate economic activity: An overview. Journal of Money, Credit, and Banking, 20(3), 559-596.

Han, L., Fraser, S., \& Storey, D.J. (2009). Are good or bad borrowers discouraged from applying for loans? Evidence from US small business credit markets. Journal of Banking \& Finance, 33(2), 415424.

Harhoff, D., \& Körting, T. (1998). Lending relationships in Germany - Empirical evidence from survey data. Journal of Banking \& Finance, 22(10-11), 1317-1353.

Harrison, A., \& McMillan, M. (2003). Does direct foreign investment affect domestic firm credit constraints? Journal of International Economics, 61(1), 73-100.

Hyytinen, A., \& Pajarinen, M. (2008). Opacity of young businesses: Evidence from rating disagreements. Journal of Banking \& Finance, 32(7), 1234-1241.

Kim, G.O. (2006). Do equally owned small businesses have equal access to credit? Small Business Economics, 27(4-5), 369-386.

Kon, Y., \& Storey, D.J. (2003). A theory of discouraged borrowers. Small Business Economics, 21(1), 37-49.

Levenson, A.R., \& Willard, K.K. (2000). Do firms get the financing they want? Measuring credit rationing experienced by small businesses in the U.S. Small Business Economics, 14(2), 83-94.

Lin, H. (2011). Foreign bank entry and firms' access to bank credit: Evidence from China. Journal of Banking \& Finance, 35(4), 1000-1010.

Parker, S.C., \& Van Praag, C.M. (2006). Schooling, capital constraints, and entrepreneurial performance: The endogenous triangle. Journal of Business \& Economic Statistics, 24(4), 416-431.

Petersen, M., \& Rajan, R. (1994). The benefits of lending relationships, evidence from small business data. The Journal of Finance, 49(1), 3-37.

Petersen, M., \& Rajan, R. (1995). The effect of credit market competition on lending relationships. The Quarterly Journal of Economics, 110(2), 407-443.

Peterson, M.F., Arregle, J.-L., \& Martin, X. (2012). Multilevel models in international business research. Journal of International Business Studies, 43(5), 451-457.

Raudenbush, S.W., \& Bryk, A.S. (2002). Hierarchical linear models. Applications and data analysis methods (2nd edition). Sage Publications.

Raudenbush, S.W., Bryk, A.S., Cheong, Y.F., Congdon Jr., R.T., \& Du Toit, M. (2011). HLM 7: Hierarchical Linear and Nonlinear Modeling. Scientific Software International, Inc.

Schiantarelli, F., \& Sembenelli, A. (2000). Form of ownership and financial constraints. Empirica, 27(2), 175-192.

Stein, J. (2002). Information production and capital allocation: Decentralized versus hierarchical firms. Journal of Finance, 57(5), 1891-1921.

Stiglitz, J.E., \& Weiss, A. (1981). Credit rationing in markets with imperfect information. The American Economic Review, 71(3), 393-410.

Storey, D.J. (2004). Racial and gender discrimination in the micro firms credit market? Evidence from Trinidad and Tobago. Small Business Economics, 23(5), 401-422.

St. Pierre, J., \& Bahri, M. (2011). The determinants of risk premium: The case of bank lines of credit granted to SMEs. Journal of Developmental Entrepreneurship, 16(4), 459-476. 
Turk-Ariss, R. (2010). On the implications of market power in banking: Evidence from developing countries. Journal of Banking \& Finance, 34(4), 765-775.

The World Bank (2008). Finance for all? Policies and pitfalls in expanding access. World Bank Policy Research Report.

Van Praag, C.M., \& Versloot, P.H. (2007). What is the value of entrepreneurship? A review of recent research. Small Business Economics, 29(4), 351-382.

Wagenvoort, R. (2003a). Are finance constraints hindering the growth of SMEs in Europe? EIB Papers, $7(2), 22-50$.

Wagenvoort, R. (2003b). SME Finance in Europe: Introduction and overview. EIB Papers, 8(2), 10-20.

Williamson, O. (1975), Markets and hierarchies, analysis and antitrust implications: a study in the economics of internal organization, New York: Free Press. 
Table 1. Perceived difficulty of loan accessibility among SMEs in the EU.

\begin{tabular}{|c|c|c|c|c|c|c|c|c|}
\hline & \multicolumn{3}{|c|}{ Panel A: All SMEs } & \multicolumn{2}{|c|}{ Panel B: By firm age } & \multicolumn{3}{|c|}{ "Panel C: By firm size } \\
\hline & & & & $<10$ years & $>=10$ years & 1-9 (micro) & $\begin{array}{c}10-49 \\
\text { (small) }\end{array}$ & $\begin{array}{c}50-249 \\
\text { (medium) }\end{array}$ \\
\hline Country & Observ. & \% Easy & \% Difficult & \% Difficult & \% Difficult & \% Difficult & \% Difficult & \% Difficult \\
\hline Austria & 121 & 0.56 & 0.44 & 0.44 & 0.44 & 0.45 & 0.40 & 0.40 \\
\hline Belgium & 146 & 0.55 & 0.45 & 0.42 & 0.45 & 0.50 & 0.20 & 0.25 \\
\hline Denmark & 138 & 0.90 & 0.10 & 0.22 & 0.06 & 0.09 & 0.17 & 0.10 \\
\hline Finland & 79 & 0.96 & 0.04 & 0.09 & 0.03 & 0.04 & 0.05 & 0.09 \\
\hline France & 270 & 0.62 & 0.38 & 0.40 & 0.38 & 0.39 & 0.26 & 0.45 \\
\hline Germany & 242 & 0.14 & 0.86 & 0.76 & 0.87 & 0.86 & 0.86 & 0.64 \\
\hline Greece & 84 & 0.72 & 0.28 & 0.28 & 0.28 & 0.29 & 0.25 & 0.20 \\
\hline Ireland & 53 & 0.84 & 0.16 & 0.06 & 0.20 & 0.17 & 0.17 & 0.09 \\
\hline Italy & 236 & 0.42 & 0.58 & 0.67 & 0.52 & 0.58 & 0.59 & 0.56 \\
\hline Luxembourg & 64 & 0.40 & 0.60 & 0.72 & 0.50 & 0.64 & 0.50 & 0.38 \\
\hline Netherlands & 137 & 0.45 & 0.55 & 0.63 & 0.43 & 0.58 & 0.44 & 0.35 \\
\hline Portugal & 59 & 0.63 & 0.37 & 0.50 & 0.15 & 0.38 & 0.20 & 0.31 \\
\hline Spain & 201 & 0.72 & 0.28 & 0.36 & 0.20 & 0.28 & 0.30 & 0.21 \\
\hline Sweden & 187 & 0.60 & 0.40 & 0.43 & 0.22 & 0.42 & 0.34 & 0.15 \\
\hline United Kingdom & 209 & 0.79 & 0.21 & 0.24 & 0.21 & 0.21 & 0.24 & 0.12 \\
\hline EU 15 & 2,226 & 0.59 & 0.41 & 0.46 & 0.39 & 0.42 & 0.38 & 0.29 \\
\hline Cyprus & 79 & 0.76 & 0.24 & 0.24 & 0.25 & 0.25 & 0.16 & 0.22 \\
\hline Czech Republic & 155 & 0.53 & 0.47 & 0.44 & 0.50 & 0.48 & 0.42 & 0.37 \\
\hline Estonia & 73 & 0.79 & 0.21 & 0.23 & 0.18 & 0.32 & 0.09 & 0.08 \\
\hline Hungary & 153 & 0.43 & 0.57 & 0.58 & 0.54 & 0.57 & 0.58 & 0.39 \\
\hline Latvia & 67 & 0.77 & 0.23 & 0.27 & 0.15 & 0.30 & 0.09 & 0.19 \\
\hline Lithuania & 71 & 0.66 & 0.34 & 0.27 & 0.48 & 0.37 & 0.30 & 0.29 \\
\hline Malta & 58 & 0.57 & 0.43 & 0.25 & 0.47 & 0.37 & 0.53 & 0.22 \\
\hline Poland & 228 & 0.49 & 0.51 & 0.58 & 0.47 & 0.51 & 0.54 & 0.56 \\
\hline Slovakia & 84 & 0.56 & 0.44 & 0.39 & 0.54 & 0.46 & 0.41 & 0.19 \\
\hline Slovenia & 95 & 0.67 & 0.33 & 0.34 & 0.32 & 0.37 & 0.14 & 0.19 \\
\hline EU 10 & 1,063 & 0.58 & 0.42 & 0.41 & 0.42 & 0.45 & 0.34 & 0.26 \\
\hline EU 25 & 3,289 & 0.58 & 0.42 & 0.44 & 0.40 & 0.43 & 0.37 & 0.28 \\
\hline
\end{tabular}

Source: Flash Eurobarometer Survey on Access to Finance (No. 174 and No. 184). "\% Easy" represents the weighted percentage of firms responding "very easy"

or "fairly easy" to the question "Would you say that today, access to loans granted by banks is very easy, fairly easy, fairly difficult or very difficult?";

"\% Difficult represents the weighted percentage of firms responding "very difficult" or "fairly difficult".

The distinction between the two age categories ( $<10$ years versus $>=10$ years) ensures enough observations for each country. However, for two countries, there are

less than 10 "older" firms (i.e., Ireland and Finland); therefore, the threshold for these countries is set at 20 years. 
Table 2. Correlation matrix firm-level and country-level variables.

\begin{tabular}{|c|c|c|c|c|c|c|c|c|c|c|c|c|c|c|c|c|c|c|c|c|c|c|c|c|c|}
\hline \multirow[b]{2}{*}{ Firm level } & \multicolumn{3}{|c|}{ sample averages } & \multicolumn{22}{|c|}{ Pearson correlation coefficients } \\
\hline & EU 25 & EU 15 & EU 10 & 1 & 2 & 3 & 4 & 5 & 6 & 7 & 8 & 9 & 10 & 11 & 12 & 13 & 14 & 15 & 16 & 17 & 18 & 19 & 20 & 21 & 22 \\
\hline 1. Age $<10$ & 0.36 & 0.32 & 0.46 & & & & & & & & & & & & & & & & & & & & & & \\
\hline 2. Age $10-20$ & 0.29 & 0.21 & 0.45 & -.44 & & & & & & & & & & & & & & & & & & & & & \\
\hline 3. Age $20-30$ & 0.08 & 0.10 & 0.03 & -.21 & -.18 & & & & & & & & & & & & & & & & & & & & \\
\hline 4. Age $>30^{\mathrm{a}}$ & 0.27 & 0.37 & 0.05 & -.47 & -.41 & -.20 & & & & & & & & & & & & & & & & & & & \\
\hline 5. Empl. 1-9 (micro) & 0.81 & 0.83 & 0.77 & .10 & -.01 & .01 & -.10 & & & & & & & & & & & & & & & & & & \\
\hline 6. Empl. 10-49 (small) & 0.15 & 0.14 & 0.17 & -.03 & .02 & .01 & .00 & -.68 & & & & & & & & & & & & & & & & & \\
\hline 7. Empl. 50-249 (medium) ${ }^{\mathrm{a}}$ & 0.03 & 0.03 & 0.05 & -.10 & -.02 & -.02 & .14 & -.50 & -.30 & & & & & & & & & & & & & & & & \\
\hline 8. Dynamics: Employment & 1.04 & 1.02 & 1.08 & .09 & .00 & -.04 & -.07 & -.12 & .06 & .08 & & & & & & & & & & & & & & & \\
\hline 9. Dynamics: Cash flow & 1.07 & 1.09 & 1.01 & .03 & -.04 & -.02 & .02 & -.07 & .02 & .07 & .20 & & & & & & & & & & & & & & \\
\hline 10. Dynamics: Investments & 1.12 & 1.11 & 1.13 & .10 & -.03 & -.02 & -.06 & -.04 & -.01 & .06 & .27 & .23 & & & & & & & & & & & & & \\
\hline 11. Previous loan & 0.60 & 0.64 & 0.52 & -.06 & -.03 & .03 & .07 & -.14 & .07 & .11 & .03 & .01 & .02 & & & & & & & & & & & & \\
\hline 12. Ownership: Family & 0.83 & 0.86 & 0.77 & -.03 & .01 & .01 & .01 & .22 & -.03 & -.24 & -.02 & -.08 & -.02 & .05 & & & & & & & & & & & \\
\hline 13. Ownership: Domestic ${ }^{a}$ & 0.07 & 0.06 & 0.08 & .05 & -.04 & .00 & -.01 & -.15 & .03 & .16 & -.01 & .04 & .01 & -.02 & -.58 & & & & & & & & & & \\
\hline 14. Ownership: Foreign & 0.03 & 0.02 & 0.05 & .03 & -.02 & -.01 & -.01 & -.16 & .02 & .19 & .02 & .06 & .00 & -.02 & -.44 & -.08 & & & & & & & & & \\
\hline 15. Ownership: Other & 0.07 & 0.06 & 0.10 & -.02 & .03 & -.01 & -.00 & -.04 & .00 & .05 & .02 & .03 & .01 & -.04 & -.55 & -.10 & -.07 & & & & & & & & \\
\hline 16. Sector: Construction ${ }^{a}$ & 0.12 & 0.13 & 0.11 & -.02 & .01 & .01 & .00 & -.03 & .04 & -.01 & -.02 & -.00 & -.01 & .00 & .03 & .00 & -.03 & -.02 & & & & & & & \\
\hline 17. Sector: Finance & 0.02 & 0.02 & 0.03 & -.03 & .02 & -.02 & .02 & .02 & -.05 & .03 & .04 & .06 & .04 & -.05 & -.09 & .03 & -.00 & .11 & -.06 & & & & & & \\
\hline 18. Sector: Production & 0.14 & 0.13 & 0.17 & -.02 & -.04 & -.01 & .06 & -.23 & .08 & .20 & -.02 & -.03 & .02 & .10 & -.05 & .03 & .08 & -.02 & -.19 & -.08 & & & & & \\
\hline 19. Sector: Raw materials & 0.01 & 0.01 & 0.01 & -.01 & .02 & -.00 & -.00 & -.03 & .01 & .03 & .02 & -.01 & .02 & .02 & .02 & -.02 & .00 & -.01 & -.05 & -.02 & -.06 & & & & \\
\hline 20. Sector: Service businesses & 0.13 & 0.14 & 0.12 & .04 & .05 & -.03 & -.08 & .05 & -.04 & -.03 & .03 & .04 & .02 & -.10 & -.07 & .01 & .01 & .09 & -.14 & -.06 & -.19 & -.05 & & & \\
\hline 21. Sector: Service consumers & 0.14 & 0.13 & 0.16 & .03 & .01 & .01 & -.05 & .03 & -.01 & -.03 & .01 & .02 & .05 & -.01 & -.04 & .03 & -.03 & .06 & -.15 & -.06 & -.20 & -.05 & -.15 & & \\
\hline 22. Sector: Trade & 0.39 & 0.40 & 0.36 & -.02 & -.03 & .01 & .04 & .16 & -.05 & -.14 & -.02 & -.03 & -.08 & .01 & .11 & -.06 & -.02 & -.09 & -.26 & -.11 & -.34 & -.09 & -.27 & -.28 & \\
\hline 23. Sector: Transport & 0.04 & 0.04 & 0.05 & -.00 & .02 & .01 & -.02 & -.00 & .01 & -.01 & .01 & -.02 & .01 & -.02 & .02 & .01 & -.01 & -.03 & -.08 & -.03 & -.11 & -.03 & -.08 & -.09 & -.15 \\
\hline Country-level & & & & 24 & 25 & 26 & & & & & & & & & & & & & & & & & & & \\
\hline 24. Log(GDP per capita) & 9.92 & 10.17 & 9.54 & & & & & & & & & & & & & & & & & & & & & & \\
\hline 25. Concentration & 1,171 & 931 & 1,531 & -.33 & & & & & & & & & & & & & & & & & & & & & \\
\hline 26. \% Foreign owned & 44.28 & 27.85 & 68.94 & -.42 & .33 & & & & & & & & & & & & & & & & & & & & \\
\hline 27. Bank size (\% of GDP) & 3.66 & 2.36 & 5.60 & .07 & .28 & .26 & & & & & & & & & & & & & & & & & & & \\
\hline Observations firm level EU 25 & 3,289 & & & & & & & & & & & & & & & & & & & & & & & & \\
\hline Observations firm level EU 15 & 2,226 & & & & & & & & & & & & & & & & & & & & & & & & \\
\hline Observations firm level EU 10 & 1,063 & & & & & & & & & & & & & & & & & & & & & & & & \\
\hline Observations country level & 25 & & & & & & & & & & & & & & & & & & & & & & & & \\
\hline
\end{tabular}


Table 3. Results of hierarchical binomial logit regressions.

\begin{tabular}{|c|c|c|c|c|c|c|c|c|c|c|}
\hline \multirow[b]{2}{*}{ Firm level } & \multicolumn{2}{|c|}{ Model 1} & \multicolumn{2}{|c|}{ Model 2} & \multicolumn{2}{|c|}{ Model 3} & \multicolumn{2}{|c|}{ Model 4} & \multicolumn{2}{|c|}{ Model 5} \\
\hline & coeff. & s.e. & coeff. & s.e. & coeff. & s.e. & coeff. & s.e. & coeff. & s.e. \\
\hline Age $<10$ & $0.35 * * *$ & $(0.10)$ & $0.36 * * *$ & $(0.11)$ & $0.37 * * *$ & $(0.12)$ & $0.34 * * *$ & $(0.11)$ & $0.37 * *$ & $(0.16)$ \\
\hline Age $10-20$ & 0.09 & $(0.10)$ & 0.10 & $(0.11)$ & 0.10 & $(0.12)$ & 0.07 & $(0.12)$ & 0.00 & $(0.16)$ \\
\hline Age 20-30 & $-0.30 *$ & $(0.16)$ & $-0.31 * *$ & $(0.15)$ & $-0.32 * *$ & $(0.16)$ & $-0.33^{* *}$ & $(0.16)$ & $-0.44 * *$ & $(0.18)$ \\
\hline Employees 1-9 (micro) & $0.28 * *$ & $(0.12)$ & $0.29 * *$ & $(0.12)$ & $0.30 * *$ & $(0.12)$ & & & $0.34 * *$ & $(0.14)$ \\
\hline Employees 10-49 (small) & 0.15 & $(0.11)$ & 0.15 & $(0.11)$ & 0.15 & $(0.12)$ & & & 0.14 & $(0.11)$ \\
\hline Turnover $<500 \mathrm{k}$ & & & & & & & $0.43^{* * *}$ & $(0.12)$ & & \\
\hline Turnover 500k-2500k & & & & & & & $0.38 * * *$ & $(0.12)$ & & \\
\hline Turnover 2500k-5000k & & & & & & & 0.14 & $(0.16)$ & & \\
\hline Dynamics: Employment & $-0.17 * * *$ & $(0.05)$ & $-0.18 * * *$ & $(0.05)$ & $-0.19 * * *$ & $(0.06)$ & $-0.17 * * *$ & $(0.06)$ & $-0.25 * * *$ & $(0.06)$ \\
\hline Dynamics: Cash flow & $-0.15^{* * *}$ & $(0.05)$ & $-0.16^{* * *}$ & $(0.04)$ & $-0.16^{* * *}$ & $(0.06)$ & $-0.15^{* * *}$ & $(0.06)$ & $-0.15^{* * *}$ & $(0.05)$ \\
\hline Dynamics: Investments & $-0.11^{*}$ & $(0.06)$ & $-0.11^{*}$ & $(0.06)$ & $-0.12^{*}$ & $(0.06)$ & $-0.12 *$ & $(0.06)$ & $-0.13^{*}$ & $(0.08)$ \\
\hline Previous loan & 0.00 & $(0.09)$ & 0.00 & $(0.09)$ & 0.00 & $(0.08)$ & 0.00 & $(0.08)$ & & \\
\hline Ownership: Family & 0.13 & $(0.08)$ & 0.12 & $(0.08)$ & 0.13 & $(0.14)$ & 0.08 & $(0.14)$ & 0.14 & $(0.13)$ \\
\hline Ownership: Foreign & 0.01 & $(0.14)$ & 0.00 & $(0.15)$ & -0.00 & $(0.21)$ & 0.03 & $(0.21)$ & $0.30 *$ & $(0.16)$ \\
\hline Ownership: Other & -0.04 & $(0.14)$ & -0.04 & $(0.14)$ & -0.04 & $(0.19)$ & -0.08 & $(0.19)$ & -0.12 & $(0.20)$ \\
\hline Sector: Finance & -0.15 & $(0.26)$ & -0.16 & $(0.27)$ & -0.16 & $(0.29)$ & -0.17 & $(0.28)$ & -0.24 & $(0.27)$ \\
\hline Sector: Production & 0.05 & $(0.15)$ & 0.05 & $(0.15)$ & 0.05 & $(0.14)$ & 0.05 & $(0.14)$ & 0.09 & $(0.14)$ \\
\hline Sector: Raw materials & -0.22 & $(0.26)$ & -0.22 & $(0.26)$ & -0.22 & $(0.33)$ & -0.19 & $(0.33)$ & -0.11 & $(0.41)$ \\
\hline Sector: Service businesses & 0.08 & $(0.15)$ & 0.08 & $(0.15)$ & 0.08 & $(0.15)$ & 0.09 & $(0.15)$ & 0.09 & $(0.18)$ \\
\hline Sector: Service consumers & 0.11 & $(0.15)$ & 0.10 & $(0.15)$ & 0.11 & $(0.15)$ & 0.10 & $(0.15)$ & 0.23 & $(0.18)$ \\
\hline Sector: Trade & 0.12 & $(0.14)$ & 0.12 & $(0.14)$ & 0.12 & $(0.13)$ & 0.17 & $(0.13)$ & 0.17 & $(0.16)$ \\
\hline Sector: Transport & 0.09 & $(0.17)$ & 0.09 & $(0.17)$ & 0.10 & $(0.21)$ & 0.11 & $(0.21)$ & 0.26 & $(0.21)$ \\
\hline \multicolumn{11}{|l|}{ Country-level } \\
\hline Log(GDP per capita) & & & -0.16 & $(0.38)$ & 1.07 & $(0.83)$ & -0.10 & $(0.49)$ & -0.22 & $(0.40)$ \\
\hline Concentration/1000 & & & $-0.48 * *$ & $(0.20)$ & $-0.57 * *$ & $(0.21)$ & $-0.48 * *$ & $(0.23)$ & $-0.58 * * *$ & $(0.20)$ \\
\hline \% Foreign owned/100 & & & -0.09 & $(0.40)$ & 1.77 & $(1.07)$ & -0.12 & $(0.61)$ & -0.18 & $(0.40)$ \\
\hline Bank size (\% of GDP) & & & $0.02 *$ & $(0.01)$ & 0.04 & $(0.03)$ & 0.02 & $(0.03)$ & $0.02 *$ & $(0.01)$ \\
\hline EU $15 \times \%$ Foreign owned $/ 100$ & & & & & $-3.97 * *$ & $(1.66)$ & & & & \\
\hline Observations firm level & 3,289 & & 3,289 & & 3,289 & & 3,289 & & 2,093 & \\
\hline Observations country level & 25 & & 25 & & 25 & & 25 & & 25 & \\
\hline Max. value log likelihood & $-4,568$ & & $-4,586$ & & $-4,598$ & & $-4,589$ & & $-2,933$ & \\
\hline
\end{tabular}

* Significant at $0.10 ; *$ at $0.05 ; * * *$ at 0.01 (two-tailed tests). Dependent variable takes a value of 1 (access to loans is perceived as difficult) or 0 (access to loans is perceived as easy). Reference categories: Age >30; Employees 50-249 (medium); Turnover >500k; Ownership: Domestic; Sector: Construction or civil engineering. Robust standard errors are displayed between parentheses (robust standard errors could not be computed for Model 3 and Model 4; regular standard errors are computed instead). The estimates of the intercepts are not reported, but are available upon request. Model 3 contains the EU 15 dummy variable; its estimates of the coefficient and standard error are available upon request as well. Convergence is achieved after 7 (macro) iterations at most in each model. The iteration process stops when the largest parameter estimate change is less than 0.000001. 
Table 4. Size of most recent loan, by firm age.

\begin{tabular}{|c|c|c|c|c|}
\hline & \multirow{2}{*}{$\begin{array}{l}\% \text { of SMEs that } \\
\text { made use of loan } \\
\text { in the past (\% } \\
\text { for which } \\
\text { previous loan=1) }\end{array}$} & \multicolumn{3}{|c|}{$\begin{array}{l}\text { Distribution of responses to the question "What } \\
\text { was the approximate amount of the last loan } \\
\text { which your company applied for?" } \mathrm{b}\end{array}$} \\
\hline & & $<25,000 €$ & $\begin{array}{c}25,000- \\
100,000 €\end{array}$ & $>100,000 €$ \\
\hline \multicolumn{5}{|c|}{ Panel A } \\
\hline EU 25: all SMEs & 0.60 & 0.36 & 0.37 & 0.26 \\
\hline EU 25: micro firms (employees 1-9) & 0.58 & 0.43 & 0.38 & 0.19 \\
\hline EU 25: small firms (employees 10-49) & 0.69 & 0.15 & 0.37 & 0.48 \\
\hline EU 25: medium firms (employees 50-249) & 0.72 & 0.06 & 0.19 & 0.75 \\
\hline \multicolumn{5}{|c|}{ Panel B } \\
\hline EU 15: all SMEs & 0.64 & 0.34 & 0.39 & 0.28 \\
\hline EU 15: micro firms (employees 1-9) & 0.62 & 0.38 & 0.41 & 0.21 \\
\hline EU 15: small firms (employees 10-49) & 0.73 & 0.15 & 0.35 & 0.50 \\
\hline EU 15: medium firms (employees 50-249) & 0.75 & 0.06 & 0.16 & 0.79 \\
\hline \multicolumn{5}{|c|}{ Panel C } \\
\hline EU 10: all SMEs & 0.52 & 0.44 & 0.32 & 0.24 \\
\hline EU 10: micro firms (employees 1-9) & 0.48 & 0.57 & 0.30 & 0.13 \\
\hline EU 10: small firms (employees 10-49) & 0.62 & 0.14 & 0.42 & 0.44 \\
\hline EU 10: medium firms (employees 50-249) & 0.70 & 0.06 & 0.23 & 0.71 \\
\hline
\end{tabular}

${ }^{b}$ Note that the percentages in the three columns add to 1.00 (=100\%) in each row;

Source: Flash Eurobarometer Survey on Access to Finance (No. 174 and No. 184). 